\title{
ON THE FORMATION OF METHODOLOGICAL COMPETENCE OF STUDENTS OF PHILOLOGY
}

\section{Bronislava Rubinska ${ }^{1}$}

DOI: https://doi.org/10.30525/978-9934-588-15-0-17

Abstract. The article is devoted to the formation of methodological competence of students of Philology. We created modern basis for the essence of the category "content of training", the inalienable part of which is the choice of philologists training content". The aim of this article was to show how to change the content of training for the students of Philology and construction of content of foreign languages training as one of the main controllable factors. Having reviewed studies of many scientists we came to the conclusion that in the definition of this notion much depends on the approach chosen, the subject group of the students and many other factors. Methodological competence is a constituent of professional competence like red rose is a constituent of flowers group of Flora. In the narrow meaning "methodological competence" is understood as content analysis, in the wide meaning the notion understanding depends on the approach. If the approach is competence-oriented the essence of the category is considered to be competence (combination of skills, attitudes and knowledge), which marks are programs content, thus key competencies are concerned with methodological culture of students of philology. If it is activity approach, competence is the key category and speech acts are the essence of speech activities, which marks are levels of communication, thus key competencies are concerned with content of knowledge and teaching and translation competency. The modern approach should integrate the best in them on a new spiral of research and be the unity of these two. The formation of intuition in chosen situations may become crucial in the formation of it. Then methodological competency and professional competency are the essence of the category and the key competencies of the students of philology should be based on the concrete choice of the content of learning so that the factors that influence it will become controllable.

\footnotetext{
${ }^{1} \mathrm{PhD}$ in Pedagogy, Associate Professor,

National University of Life and Environmental Sciences of Ukraine, Ukraine

(C) Bronislava Rubinska
} 


\section{Introduction}

Higher education qualifications show tendency to lose their actual value within short period of time in modern society. The necessity to renew the level of professional training in any sphere of life turns into a must, as far as the generic and subject specific competencies totalities are concerned. Life Long Learning is a means of improving competencies totalities, which shows signs of XXI century personality's professionalism [1, p. 230; 35]. It will become possible to realize such education and to make it more effective if we create modern basis for the essence of the category "content of training" in our research. This category is closely connected with another category - "content of education", the inalienable part of which is the choice of the philologists' content of training on the basis of activities and competency-oriented approach. Many researchers think that the idea of competency is the idea of an open order on content of education [1]. We can base our research on the description and picture in the book "Lectures. Basics of Pedagogics" [32]. According to it the main components of the content of general education are the system of knowledge (notions, terms, facts, laws, theories); skills and activities (practical and intellectual), special and general educational; experience of creative activity, transfer of knowledge into a new situation, seeing of a new problem, new function of an object, the structure of an object, alternative thinking; evaluation of values attitude, evaluation knowledge, knowledge of the norms of attitude, skills to stick to the norms of behavior [32]. The system of education in Ukraine has undergone several stages. The postsoviet stage started from 1991. The basis for the formation of the content of education was the program "Education" (Ukraine of the XXI century), 1993, the Constitution of Ukraine, 1996, Zakon Ukrainy «Pro osvitu» (Pryiniattia vid 05.09.2017. Nabrannia chynnosti 28.09.2017), Zakon Ukrainy "Pro vyshchu Osvitu" [37; 38].

\section{Research problem and literature review}

It is necessary to clarify and specify this category from the positions of educational activity. «Educational activity turning into research activity becomes the object of research... It is competency approach that teaches a student to learn». [18]. We agree with those scientists that consider it to be a complex phenomenon which includes not only activity itself but also personal attitude to it and to the subject of activity, including personal and 
subject-oriented. Finding out the new ways of solving the research problem in conditions of modern education reform that takes place in Ukraine we directly connect it with the solution of strategic tasks of Ukrainian education in the context of Bologna process requirements (worked out by A. Alexiuk, B. Bokut, Ya. Bolubash, I. Zyazun, L. Kondrashova, V. Kremen, N. Kuzmina, Z. Kurliand, O. Molibog, N. Nychkalo and others), priorities in training future highly qualified specialist, who is able to participate in joint activities (worked out by M. Bachtin, O. Leontiev, Z. Kornayeva, I. Bim and others) as well as with European ones.

In Europe in the book "Training Foreign and second language teachers: European Challenges, Success and Perspectives" teacher training system in different European countries is discussed. The system consists of input, transformation process and output elements. The book is focused on the process of transformation in the system. The input and output elements are not in the focus of attention in it. "The training process is considered from two perspectives for each of the five countries discussed: a descriptive dimension of the current training routes through which necessary teaching qualifications are obtained; and an evaluation as to the degree to which the training fits the purpose of teaching foreign and second languages in state secondary schools. Teacher training is described within the contexts of national policies for language learning and the nature of providers and courses, along with details of opportunities for teaching practice" [32]. This book gives a fundamental view of the research problem and we will base our understanding on the following facts. In Germany the main characteristic features of this process are: high degree of decentralization due to Germany's federal system in each of the 16 federal states; 3 stages of training(higher education training, pedagogical practice at school, in-service training for fully employed teachers); different difficulties, caused by the changes in laws, which differ from one state to another; absence of national system of exams; limited mobility of teachers because of difference in training, interdisciplinary centers that provide connection between different stages of training. The article on the French system of training touches upon only the system of training of MAs, leaving without consideration the bachelor's stage and in-service training.

Unlike Germany the system in France is centralized. The students are given possibility to choose from different approaches and courses. The 
absence of national system of exams stimulates competition. The entrance exams check academic knowledge, not communication skills, though oral part and situations with elements of teaching tasks are introduced. The accent is given to theoretical training of teachers, rather than to formation of professional competence. In Ukraine the system is also centralized, there are 3 stages of training like in Germany, national system of exams stimulates competition. As to the teachers of foreign languages, their training is focused on obtaining linguistic knowledge rather than formation of competencies. The system provides connection between different stages of training, there is an obligatory in -service retraining every five years. New elements in the input of the system were introduced: young unexperienced teachers receive a tutor that will help them to feel at ease in their professional activities. There are examples of integrated courses, such as "English language improvement", "Technology and Language Training" in Kyiv State Linguistic University, which illustrate the modern approach to the problem. Another feature is interdisciplinary integration, diversification and introduction of information-communication technologies. The next new element is the focus on intercultural aspects in teaching foreign languages. In Russia there are such elements as new approaches (competence-oriented and active position in life). It includes such components as mastering knowledge in Pedagogics and Methods of teaching on education process and professional skills, professional and individual development: creative self-realization in professional activities. The system of education in Uzbekistan was also analyzed. It is also centralized, new laws govern it, the system of evaluation, both inner and outer testing for finding out the level of knowledge, language and professional skills of teachers of foreign languages, exist there. We agree with the conclusion of O. Blanvilen that there is a different degree of autonomy in the system of training of a teacher. Though they are all based on the documents such as "Recommendation on Key Competences for Lifelong Learning", TUNING Educational Structures in Europe II Universities' contribution to the Bologna Process. University of Deusto, University of Groningen, they much depend on the national policy and the system of education. The progress in the change of this system is going on and it can be intensified due to the life-long learning that now exist in Ukraine.

Gardening is our hobby. My flowers cannot be long abandoned and well dried. Long ago gone are the mashines and hours of my parents' work that lie 
beneath. Nowadays all that is left is myself and the flowers I'd like to grow, which need great effort and a lot of water and chemicals to protect and feed them. They are finally grown up to flourish to please our eyes with beautifulness and our nostrils with smell. But can we influence them? Our influence on them can be controllable, but there are factors that are not controllable. In controllable factors we can rely on our cognition, experience and modern system of gardening to reveal the treasures that were left behind in the rapidity and quality of growing, which were left behind by my predecessors. As far as uncontrollable factors are concerned, they are the weather conditions like draughts, winds, rains and others. But there are a lot of factors that can be controlled. Of course, the flowers I am referring to are students. The improvement of the content of training students who study foreign languages in higher education is connected with more successive usage of activities approach in teaching. Students' activities are much more variable now. After Ukraine entered the EU system of education and has been participating in Bologna process students were given an opportunity to study abroad, participate in international projects, conduct scientific research and report about its results at the international conferences and symposiums, work as interpreters there who help people from different countries to understand each other. But our analysis has shown that bachelors and masters have certain difficulties in communication in some spheres, including scientific one. However, these students much like the abandoned flowers struggle to be recognized for both their beauty and potential for success.

As their teacher, I often feel like a lone gardener who has unlimited access to control their success and results of studying, and although it can be a difficult challenge to uncover these buds, the feeling of zeal and passion when one is opened and flourish is second to none.

In the world of education, it is surprising that these students have been relegated to near abandonment, while their dominant culture of highly qualified educators have been transitioned into university bound advanced courses, these students have simply been left uncontrollable due to a lot of factors. One of the controllable factors that can influence their professional formation is the question of what to teach, but it hasn't been fully researched.

We would like to analyze the research and publications of scientists on the choice of content of training students who study foreign languages and in whom methodological competence is formed. The notion "content of train- 
ing" has been researched by a lot of scientists in Ukraine, Russia, Belorussia and abroad. Such researchers as Y.I. Passov, V.L. Skalkin, N.S. Doroshenko, Z.V. Kornayeva, R.V. Fastovets, I.L. Bim, L.A. Karimova, O.I. Zhdanko and many others $[3 ; 5 ; 6 ; 9 ; 10 ; 11 ; 24 ; 28 ; 30 ; 33]$ have written research articles, dissertations and books on it. But the problem of the integration of new principles and other constitutive elements of this category hasn't been fully researched yet. We have researched some new principle of the choice of content of teaching such as integration. We base our understanding of this principle on the research of Puck M.S. [23, p. 189-190]. In literature on Pedagogics there are publications in which the pedagogical, didactic and methods of teaching aspects of the integration and differentiation problems in education and teaching of subjects are disclosed. In them various questions are under consideration:

- integration processes, touching the education sphere and that have positive influence on the development of pedagogical science and integration of its functions (Z.A. Malkova, N.D. Nikandrov, B.S. Gershunskiy, V.S. Shubinskiy and others);

- the necessity of the reflection in education of the integration processes, that take place in science (A.P. Beliayeva, V.N. Fedorova, I.D. Zverev, V.N. Maksimova and others);

- integration processes in pedagogical experience of the best teachers and professors and its influence on the solution of the problem of harmonization of education (G.F. Fedorets);

- methods of revealing and describing integration processes in education process (Yu.S. Tunnikov, V.S. Puck);

- the necessity of integration of contents of science, professional technical education and professional technical training of students (A.P. Belyaeva, M.N. Berulava training);

- integration between education processes and scientific research in the system of higher education (V.S. Kabacov, M.S. Puck, G.N. Fadeyev);

- getting rid of a great number of subjects and increasing effectiveness of educational process by means of integrating subjects and disciplines under study (I.Yu. Alexushyna, Yu.K. Dik, A.A. Pinsky, V.P. Solomin, V.V. Usanov and others);

- contradictions, regularities and preconditions that determine integration processes, sources and mechanisms of their mutual activities, principles 
and types of integration in science education (A.P. Belyaeva, M.N. Burulava, L.F. Keyran, Yu.S. Tunnikov, M.S. Puck and others).

- reformation of pedagogical thinking on the basis of integration and humanization ideas (A.P. Belyaeva, V.G. Razumovsky, L.V. Tarasov, I.M. Titova and others). We agree with her idea that it is reasonable to differentiate such components of integration as: 1) notions, which directly include integration (for example, integrative activities, integrative work);

2) notions, which express vertical structure of the integration notional space (integration between subjects, fundamentalization, interconnection, interaction, interpenetration and others);

3) notions which reflect horizontal structure of the integration notional space (intercycle integration, inner subject integration, levels of integration, facts, notions, methods, language, laws, theories, local nature picture, connection, system) [23, p. 190-191].

We will base our analysis on such understanding in our further analysis.

In psychological articles it is stated that subject-oriented communication is not well researched. But we can ground our research on such characteristics as:

1) joint aim, which unites efforts of participants of joint subject-oriented activity;

2) the existence of common goal defines and differentiates concrete tasks of each of its participants. It is made concrete in certain tasks entrusted on each participant, and can be realized only in line with joint actions;

3) speech acts(further on SA), which are realized by the participants of joint activities, are different from individual SA because they are all interconnected, each of them is based not only on individual acts, but necessarily takes into account the supposed future acts of all other mutual activity realization of the acts of its individual participant is regulated both by the reflection of the object it is aimed at but also the actions performed by other participants, and those changes in the object which are the result of it. The acts of an individual are thus built not only in accordance with the correspondence to the task and object. The individual, participating in activity, "adapts" the action performed by other people. The regulation of an individual act includes the moment of "adaptation". It makes such characteristics of action as "dynamics" more intensive. Finally, the evaluation of result complies with the demands that are determined by agreement of "mutual- 
ity" of joint activities [26, p. 235-236]. Consequently, the content of SA in joint activities is richer than the content of individual SA in person-to-person communication, as each of the participants uses in them information, which couldn't be gained without communication in collective, not using the experience of other participants of joint activity.

New technologies have also changed the content of training, so one of the most popular platforms - Kahoot has been analyzed and its content of training evaluated from the point of view of their possibility to provide all of the spheres, forms and types of students' communication [8; 26]. In it the concept 'content of training and 'methods of teaching are integrated together" and only two principles of the choice what to teach are taken into account: self-guided and inquiry-based learning.

The aim of this article is to show how to change the content of training for the students, who study in humanitarian universities and construction of content of training of foreign languages. "How we learn is as important as what we learn, and the way we're learning about our world and participating in it has changed fundamentally" [18]. According to O.O. Lavrentyeva, there is a tight correlation dependence between effectiveness of methodological training and the level of their professional teachers' culture, the degree and quality of their scientific-methodological activity, attitude to students' science and pedagogical training at school. She emphasizes that "the volume of methodological knowledge they get is limited, and that kinds of proposed scientific activities are mostly of educational and subjective-transformational character. It explains the low level of the formed methodological knowledge in scientific-theoretical training of nearly $70 \%$ of students and in methods of teaching of $60 \%$, and psychologic-pedagogical in $75 \% .55 \%$ of future teachers have false ideas of what is the role and content of research activity; the outer motivation in the choice of profession specialization in nature sciences prevails in nearly $50 \%$ of students" [13, p. 12-13].

Let us first consider the notion "content of education" which is closely connected with the notion "content of training". There are some controllable factors in its structure.

The first one is the demand in society that dictates the appearance of highly qualified specialists on the labor market. Consequently, our system's most struggling students are often given education without the requisite 
skills enumerated in the document 'ANNEX to the Proposal for a Council Recommendation on Key Competences for Lifelong Learning [1].

The second one is to satisfy the needs of society. They are simply torn off for sale and put into bouquets whose cost outweighs their perceived value on the market they wither and are thrown away. However, the fact that their initial value has not been initially recognized is not always cause for alarm because there are scientists among their professors who are always on guard to discover controllable factors that can influence them in the process of education and use them in research and teaching, show the students their true potential to become empowered members of society through research, access and support of educational system.

It is evident that our Ukrainian system of education is a complicated one and it is undergoing the process of reformation. We have set ourselves the following tasks:

1) to consider the notion "competence", "competency", "methodological competence", in the latest researches and generalize the results;

2) to study how to form methodological competence;

3) to research controllable factors in this system that can influence the result of education.

\section{Competence, competency and methodological competence}

The question of what is "competence" and "competency" has been fully researched in pedagogical literature. We will base our understanding of these categories on the latest research, where the approach to definitions of the terms under study is spiral [13]. Kuznetsova O.V., Odarchenko V.I. quote the definition of the notion in Large Dictionary of Modern Ukrainian Language: "competence originates from the Latin word "competens" (competentic), which means "appropriate, capable". "Competency is a certain sum of knowledge of a person that allows him/her to make judgements, express convincing authority idea. Competent is the one, who knows, is knowledgeable in a certain sphere of life, who has the right in accordance with his knowledge to do or decide something, make judgements about something". According to Cambrige English Dictionary "competence is the ability to do something well". A good example for teachers and learners of English is given: "Her competence as a teacher is unquestionable. He reached a reasonable level of competence in his English. The word "com- 
petency has another meaning: "an important skill that is needed to do a job: managerial competencies" [41].

They also quote the definition of competency from the document "The European Qualification Framework for Lifelong learning. (EQF). But the latest document of EU was not analyzed. In "ANNEX to the Proposal for a Council Recommendation on Key Competences for Lifelong Learning" [1] Key Competencies for life-long learning, necessary for each man during the whole life are enumerated. These are such competences as: literacy, languages competence, science, technology, engineering, mathematical competence, digital competence, personal, social and learning competence, civic competence, entrepreneurship, cultural awareness and expression. So competence as a characteristic feature of a person shouldn't be confused with competency. We agree that these notions are the objects of study of very complicated phenomena and each scientist produces new results of studying them and enriches the definition, raising it to another spiral of scientific cognition.

Another important notion under study is "methodological competence". It is understood in the narrow and wide meanings.

In the narrow meaning "methodological competence" (further on MC) is understood as:

"Benchmarking, Descriptive and inferential statistics, Coaching, Evaluation, Content analysis, Interviewing, Moderation, Network analysis, Regulatory cost analysis, Written or online surveys, Project management, Process analysis" [41].

In the wide sense $\mathrm{MC}$ is understood as a complex unity of methodological knowledge, which is a constituent of educational knowledge, and competencies.

According to Nwachukwu Ololube "Methodological knowledge is classified into the framework of educational knowledge, and it includes two types of knowledge which also belong to the field of education - the knowledge of the content of learning and the teaching knowledge" [22].

The knowledge of the content of learning refers to the content of the programs compiled by professors according to the demands of educational institution. It includes content of different pedagogical, psychological and philological disciplines studied at universities, as well as successful learning that the students should be able to actively apply in their work. 
The author makes the conclusion that it is specific because it is not exclusively of cognitive character since it also refers to the knowledge of various teaching methods and techniques, to the affective component of the teachers' personality and their methodological inventiveness in terms of working on the basis of the learned methods and techniques, but also with the methods and techniques that the teachers should certainly be able to devise on their own. Thus affective component of teacher's personality and creative abilities are included into the notion. The notion competency is tied with the situation of performance". Methodological knowledge refers to the cognitive area and includes skills, whereas competencies are related to the practical application of knowledge and skills in real life situations". We agree with the statement that methodological competencies refer to the ability of teachers to apply theoretical and experiential knowledge in their practical work with the aim of effective teaching.

It is also studied as the the basis of fundamentalization of professional training of future teachers. In the article these two notions are blended. It would be more correct to use the term "methodological competency" in it. [15] "methodological competence of the teacher is knowledge, skills and experience to implement the educational process effectively, to provide a productive educational-cognitive activity of the students, to contribute to their vital and professional selfdetermination. The essence of methodological competence is the ability of the future teacher to use methodological knowledge in accordance with the educational areas of professional activity, to apply methodological tools as a means of providing creative activity effectively". In this definition the application of methodological tools is an added element of definition, which focuses on the result of activity.

According to the research of Nataliia Maiier [17] in methods of teaching foreign languages and cultures at higher school "formation and development of future foreign language teachers' methodological competencies are provided by mastering its structural components - competencies and sub-competencies. In the process of students' methodological training to implement intercultural foreign language education, their mastering of sub-competence within lingvosociocultural competence is of great importance. A future university foreign language teacher's sub-competence as a part of lingvosociocultural competence is a complex and dynamic interplay of specific methodological knowledge and skills that enable to organise 
students' intercultural education. The future university teachers' methodological training to implement intercultural foreign language education takes place in different forms of educational process organisation. Master's students majoring in foreign language teacher education acquire methodological knowledge and skills within the normative discipline "Methods of teaching foreign languages at higher educational institutions", the elective discipline "Methods of using educational materials for the formation of foreign language communicative competence", and during student teaching period."But linguosociocultural competence is not the only one structural component of competence for Master's students majoring in foreign language teacher education. She characterizes competencies and subcompetencies as structural elements of methodological competency, which are acquired in the process of methodological training. Methodological knowledge as a component is not included into the notion under study.

This component is analyzed by other scientists. For example, Nwachukwu Ololube, analyzing methodological competence of literature students considers it mandatory to acquire. He considers the notion methodological competence in such a way: "Methodological knowledge is classified into the framework of educational knowledge, and it includes two types of knowledge which also belong to the field of education - the knowledge of the content of learning and the teaching knowledge. The knowledge of the content of learning refers to the default curriculum themes on which the students acquire basic knowledge, and this type includes knowledge and strategies, techniques and methods for successful learning that the students should be able to actively apply in their work. The teaching knowledge should be acquired by every teacher because this type of knowledge involves different teaching skills and knowledge which are acquired at teacher training faculties. The importance of methodological knowledge is evident in its comprehensiveness, because a teacher who has it and actively applies it is wellversed in the content of the subject that is taught, and at the same time masters the appropriate ways of adapting the prescribed learning content to the principles of psychology, sociology, pedagogy and didactics. «Methodological knowledge has the character of primarily experiential knowledge, and it is essentially determined by the specific purpose of its application in education». Therefore, methodological (teaching) knowledge is specific because it is not exclusively of cognitive 
character since it also refers to the knowledge of various teaching methods and techniques, to the affective component of the teachers' personality and their methodological inventiveness in terms of working on the basis of the learned methods and techniques, but also with the methods and techniques that the teachers should certainly be able to devise on their own" [22].

$\mathrm{He}$ distinguishes methodological competence and competency and bases its definition on the glossary definition of EU document. "competency should be defined as the competence for successful performance, and as an area in which someone possesses the knowledge, skills and experience". He pays more attention to the practical aspect of definition: "Methodological competencies refer to the ability of teachers to apply theoretical and experiential knowledge in their practical work with the aim of effective teaching". They are key teaching qualifications.

In the formation of methodological competence in students of Philology much depends on the approach chosen. We can roughly divide modern approaches into three groups: competence-oriented, activity and integrated. If the approach is competence-oriented the essence of the category is considered to be competence (combination of skills, attitudes and knowledge) According to Tovkanets G.V., Lendel L.V. and Kyrlik O.V., who studied competence of young learners at school the formation of such comptencies as general cultural, social and analysis and synthesis competencies are the key competencies for successful socialization of young learners. They grounded their formation at the foreign language lessons on the basis of teaching via direct life experience, through the description by a pupil of what he/she hears or sees at the lessons with the help of pantomime, method of telling stories, which helps pupils to emerge into foreign language, which marks are programs content, thus key competencies are concerned with methodological culture of pupils. The pupils are capable to speak and communicate [33].

Another approach is activities. "Competency should be defined as the competence for successful performance, and as an area in which someone possesses the knowledge, skills and experience. Methodological knowledge refers to the cognitive area and includes skills, whereas competencies are related to the practical application of knowledge and skills in real life situations [29]. In another research conclusion is made that «these approaches should be listed and described in order to present effective methodological models for the acquisition of methodological competencies of future teachers" [22]. 
The modern approach should integrate the best in them on a new spiral of research and be the unity of these two. We have considered the notions "creative activity", "creative ability" and "intuition", generalized different approaches to their definition and their role in the formation of methodological competence and integrated them. Several examples of how the results of research were taken into consideration, when writing programs and exercises for teaching students of humanities profile were given in our article [28]. We tried to develop methodological abilities in our students of philology.

Methodological abilities can be viewed as a synonym to the notion "creative abilities". Creative abilities demand from a person intensive brain activity in the process of creation, due to which it is possible to create different products of creative activity, which are characterized by novelty. As a result of joint theory of creation scientists started to study common features in scientific and artistic creation and enlarged their understanding of creation and creative abilities in this sphere. It was wrong to consider that in the process of interpreting only knowledge is important. It is necessary to form methodological competence with the help of situations that include the usage and development of intuition. We have generalized scientific approaches to the notion "methodological activities", "creative activity" and "intuition" and clarified their role in the formation of methodological competence of students-philologists in our article [28].

\section{The formation of intuition of students of philology}

Very often students make mistakes in interpretation because of gaps in understanding the variant of the English language or the type of dialect they hear or fast tempo. It happens not because of the absence of cognition but because they don't rely on their intuition. We can offer students such types of exercises, which will develop their intuition and form methodological competence. The first group will be language exercises. They will prepare students for listening comprehension and help to get rid of some gaps with the help of intuition. The second group of exercises can be called communicative. They will provide listening comprehension and interpretation activities combined. Let us illustrate the examples of these exercises.

Group 1.

1. Listen to these 4 people speaking in a great noise situation and define what variant of the English language they speak: A) BE; B) AE; C) AuE: D) NZE. 
Choose the variant of translation. A) Зі змінами у мові можуть бути пов'язані також різноманітні зміни у різних місцях.

Б) Зі змінами у мові можуть бути пов'язані також різноманітні зміни у різних розумних межах.

В) Різні розумні зміни виражені різними способами по мірі змін у мові.

Г) По мірі того як відбуваються зміни у мові вони можуть добре змінювати мову різними шляхами в різних підсистемах.

Д) Різні розумні зміни виражені різними способами по мірі змін у мові.

2. Listen to these 4 people speaking in a very fast tempo and define what variant of the English language they speak: A) BE ; B)AE; C)AuE: D)NZE.

3. Listen to these 4 people speaking and define what dialect of the English language they speak: A) East London (cockney) accent); B) Brummy (Birmingham accent, Midlands, England): C) Francophone accent (Quebec, Canada); D) Indian English accent.

Mark the variant you consider the correct answer and translation, then put aside your sheet and let's read another text. After the students finish reading or any other kind of activity ask them to look at the sheet they put aside and mark it quickly again asking their intuition "Am I right?".

You can also ask your students to learn from the past [28]. Tell them to recall a negative experience from your past translation or interpretation activity, ideally something fairly recent. "Before this thing happened, think back to whether you got any feelings that urged you to steer clear. Maybe they got a gut feeling something wasn't right in comprehension...If so, did you pay attention to that feeling or did you talk yourself out of it? Try to remember exactly how you felt. Recall as many details as possible. The more you can get in touch with the part of you that tried to warn you, the more you'll trust it next time" [28].

Another way to develop intuition is to ask your students to talk to their intuition. Tell them a story about intuition and how it helped to get a job told by Francis Cholle "You: What should I wear today? Your Unconscious: Red. You: Red what? Your Unconscious: I don't know, just something red. You: Why? Your Unconscious: Feels good. You: But I have an interview today; isn't red too aggressive? Your Unconscious: You're missing the point You: What's the point? Your Unconscious: You like red. It makes you feel happy. You: What has happiness got to do with this? Your Unconscious: Everything. You: How? Your Unconscious: You'll see; just trust me on this. 
And perhaps in doing this, because you simply feel good, your confidence exudes more at your interview, and you receive the job based on this. Perhaps your interviewer loves red, and enjoys that you were bold enough to not wear black. Perhaps the color is what makes you stand out from so many others. Who knows? The point is, you listened to your instincts and made your decision, including intuition and benefitting from it, without worrying about the logical reasons why." [5]. After it ask them to talk to their intuition about the sentence they have translated and then choose if it was correct or needs perfection because of some misunderstanding.

Group 2. Involve students into creative interpretation. It will integrate cognition and intuition. Propose them to act instead of another interpreter whose interpretation they've just listened to. Give them the opportunity to listen to the English (or Ukrainian) text and the text of interpretation with gaps. Omit in the text they listen to words that may be confusing, for example, hill - he'll, dill - deal, chip - cheap, cheep, bit - beet, beat, edge - age, wreck - rake, get - gate, manner - minor, land - lined, sat - site, man - mine etc and that contain false friends of the interpreter. Ask them to use their intuition in interpreting the text they hear and choose the right interpretation.

Another exercise will be role play, where they are proposed the following situations. "You are acting as an interpreter. You will interpret the text, which was given to you by the scientist. But after the report there are several questions which are connected with the topic of the report and you will have to interpret both the questions and the answers. Use your intuition to interpret moot points in them".

Another situation is connected with the choice of the variant of interpretation which they hear and which is done by two different interpreters. Ask them to talk to their intuition and to choose the variant they consider more appropriate. Then ask them to produce their own variant of interpretation, which is based on the variant they have chosen.

Group3 will be devoted to creative and scientific activities. The third group of situations will be connected with the research work of students. They are proposed to read a scientific article written by the student on translation and published last year. Then they are asked to write annotation to it in 3-5 sentences. Ask them to talk to their intuition to find out what the main results of that research are. Then each student will produce the annotation in the classroom first in the original and then in his/her interpretation. 
We have also analyzed the content of the training of the future philologists in programs of NULES Ukraine from this point of view. The list of methodological knowledge and competencies can also be grouped into two classes: narrow and wide. For example, in the program "Translation of business documents" we can see a mixture of what skills are the business ones, but not what skills the employers are looking for and what cognitive methodological skills students should learn. Firstly, it is written that they have "to use corresponding strategies of business negotiations during international meetings, presentations and talks", but this definition is too general as negotiations can cover anything from hard team negotiations for better terms in a contract to simple everyday situations, such as discussing the best place to have supper. Managers and CEOs may use persuasion skills with the aim of changing the customer's point of view and the interpreter has to know how to persuade with the proper business language. Sometimes interpreter can do oral translation and persuade even better than the speaker, using proper oratorical skills. Many students find this skill difficult to master. Therefore, we have to choose situations which will teach them how to use this skill. In the program we should write: "to teach them listen carefully to what one team is trying to say, keep in mind its outcome by the end of negotiations and translate it properly". When it comes to persuasion they have to be able to frame the persuasive argument by selecting certain words that bring up particular images in the mind of the listeners of the target language. Besides they have to make something more appealing because of limited availability by using certain emotionally colored words in the target language and reformulate for emphasis, using proper intonation.

The second important skill is financial and numeracy. Although they are not financiers they have to understand profit and loss accounts, management of cash flow, cost benefit ratio, read and translate financial reports, tracking the time they spend on it and translate them with correct term (either general or special) and number.

Thirdly, technological skills should also be included into programs as no interpreter or translator can ignore the technology revolution. They are either broad or narrow skills such as using Power Point or learning Prezi, different kinds of dictionaries in order to translate, understand emails language and etiquette.

As to the written business translation, according to the program, they should be able "to translate business texts from English into Ukrainian 
and vice versa with high quality", which is too general, "to write different kinds of business papers and adequately translate them from English into Ukrainian and from Ukrainian into English". The most widely used types of business papers are letters, emails and contracts. So these types of business documents should be included and the skills of their translation mastered. They should also be able "to operate general and special business terminology freely and find adequate corresponding translations of them into a target language". The most widely used terms should be chosen on the principles of frequency, stylistic neutrality, absence of polysemy. We came to the conclusion that we should form methodological knowledge and competencies of the concrete content of learning not the general one.

\section{Conclusions}

Modern demand of highly qualified specialists has made researchers find ways of improving competencies totalities, which shows signs of XXI century personality's professionalism. We came to the conclusion that we can make teaching more effective if we create modern basis for the essence of the category "content of training" in our research, which is based on the category "content of education". Having reviewed studies of many scientists we came to the conclusion that in the definition of this notion much depends on the approach chosen, the subject group of the students and many other factors. Methodological competence is a constituent of professional competence like red rose is a constituent of flowers group of Flora. In the narrow meaning "methodological competence" is understood as content analysis, in the wide meaning the notion understanding depends on the approach. If the approach is competence-oriented the essence of the category is considered to be competence (combination of skills, attitudes and knowledge), which marks are programs content, thus key competencies are concerned with methodological culture of students of philology. If it is activity approach, competence is the key category and speech acts are the essence of speech activities, which marks are levels of communication, thus key competencies are concerned with content of knowledge and teaching and translation competency. The modern approach should integrate the best in them on a new spiral of research and be the unity of these two. The formation of intuition in chosen situations may become crucial in the formation of it. Then methodological competency and professional competency 
are the essence of the category and the key competencies of the students of philology should be based on the concrete choice of the content of learning so that the factors that influence it will become controllable.

\section{References:}

1. ANNEX to the Proposal for a Council Recommendation on Key Competences for Lifelong Learning. Available at: https://ec.europa.eu/education/sites/education/ files/annex-recommendation-key-competences-lifelong-learning.pdf (accessed 18 October 2019).

2. Balayan A.R. (1971). Osnovnye komunikativnye kharakterystiki dialoga [The Main Communicative Characteristics of a Dialogue]. PhD in Philological Science Thesis, Moscow, MI of FL, pp. 1-19.

3. Bim I.L. (1979). Nekotorye problemy obuchenya dialogitsheskoy retshi [Some Problems of Teaching Dialogue Speech]. Foreign Languages at School, no. 5, pp. 20-27.

4. Borisko N.F. (1987). Obutshenye monologitsheskoy retshi s ispolzovanyem videofonogram [Teaching Oral Monologue Speech with the Usage of Videophonogramma at the Beginning stage of Language Higher Educational Establishment in the Intensive Course (on the material of the German Language]. $\mathrm{PhD}$ in Pedagogical Science Thesis, Moscow, KIof FL, Kyiv, pp. 1-226.

5. Doroshenko A.V. (1986). Pobuditelnye akty retshi i yih interpretatsya $v$ teksti [Incentive Speech Acts and their Interpretation in the Text (on the Material of the English Language) Thesis, Moscow, MIof FL, PhD in Philological Science abstract. Moscow. MGU, pp. 1-26.

6. Fastovets R.V. (1985). Metodyka obutshenya ustnomy inoyazytshnomu obshcheniyu na natshalnom etape $\mathrm{v}$ yazykovom vuze (na materyale angliyskogo yazyka) [Methods of Teaching Oral Foreign Language Communication at the Beginning Stage in a Language University (on the material of the English Language)]. PhD in Pedagogical Science Thesis, Moscow, MSI of FL, pp. 1-223.

7. KAHOOT! Support KAHOOT (2018). Some Tips for your Academic Research. Available at: https://uservoice.com/knowledgebase/ les/.. (accessed 19 October 2019).

8. Kahoot (2018). Online Tools for Teaching \& Learning. Available at: https://blogs.umass.eduarti (accessed 18 October 2019).

9. Karimova L.A. (2009). Soderzhanye i metodyki obutshenya inostrannym yazykam $\mathrm{v}$ uslovyah modernyzatsyi vysshego professionalnogo obrazovanya na prymere tehnytsheskih vuzov - utschastnikov bolonskogo protsessa [Contents and Technologies of Teaching Foreign Languages in Conditions of Modernization of Higher Professional School: on the Example of Non-humanities Profile Universities - Participants of the Bologna Process]. PhD in Pedagogical Science Thesis, Kazan, Kazan state university, pp. 1-230.

10.Klimentenko A.D., Vaisburd M.L., etc. (1984). Soderzhanye obutshenya inostrannym yazykam v shkole: organizatsya retchevoi deyatelnosty [Contents of Teaching Foreign Languages at School: Organization of Speech Activity]. Moscow: Pedagogics. (in Russian) 
11. Kornayeva Z.V (1982). Organyzatsya obutshenya dialogitsheskoi retshi v 4-5 klasah sredney shkoly(na materiali nemetskogo yazyka) [Organization of Teaching Dialogue Speech in the 4-5 Forms of a Secondary School(on the material of the German Language)] PhD in Pedagogical Science Thesis. Moscow: MGU, pp. $1-231$.

12. Kuznetsova O.V., Odarchenko V.I. (2019). Znachennya profesiynoi kompetentnosti $\mathrm{v}$ aspecti problem formuvannia osobystosti maibutnogo vchytelia [The Meaning of professional competency in the aspect of the problem of the formation of future teacher's personality]. Pedagogica and The History of Pedagogica (electronic journal), vol. 2, no. 10, pp. 24-28. Available at: http://seanewdim.com >uploads $>$ s._e._genkal_zh._yu... (accessed 19 October 2019).

13. Lavrentyeva O.O. (2016). Rozvytok metodologichnoi kultury maibutnih uchiteliv u systemi profesiynoi osvity:teoretychni aspect [The Development of methodological culture of future teachers in the system of professional education:theoretical aspects of professional and technology education]. Naukovi zapysky. Seriya: Pedagogika, no. 2(13), pp. 10-16.

14. Leontyev A.A. (1979). Pedagogytsheskoye obshchenye: monografia [Pedagogical Communication: monograph]. Moscow: Knowledge, pp. 1-47.

15. Lomov B.F. (1984). Metodologytsheskie i teoretytsheskie problemy psyhologyi: monografia [Methodological and theoretical problems of Psychology: monograph]. Moscow: Science, pp. 1-444.

16. Genkal S.E., Chernyakova Zh.Yu. (2019). The Methodological competence as the basis of fundamentalization of professional training of future teachers. Sumy State Pedagogical University named after A.S. Makarenko, Sumy, Ukraine (electroinic journal), methodological competence of the teacher of foreign languages from a configurational approach Praxis. 2013; 4(1): 108-133. Available at: https://doaj.org/ article/91ada0a77bcd44f080df87b8411b4316 (accessed 18 October 2019).

17. Maiier N. (2019). The Methodological Training of Future University Teachers to Implement Intercultural Foreign Language Education: the Competencybased Approach. Available at: http://ae.fl.kpi.ua/article/view/101358 (accessed 18 October 2019).

18. Malihin O.V. (2014). Ierarhiya kompetentnostey suchasnogo pedagoga [Interactive competency of a modern specialist in Pedagogics]. Proceedings of the 1025-richchya istoriy i osviti v Ukrayini: trudnoschi, suchasnist ta perspektivi: $\mathrm{zb}$ materialiv mizhnar. nauk. konf. (Kyiv, April15-16, 2014). Kyiv: MON, pp. 65-75.

19. Mironova T.Y. (1985). Obuchenye ustnoy ekspressivnoy retchy $\mathrm{v}$ intensivnomu kursi inozemnoy movy (Problemy soderzhanya obutchenya) [Teaching Oral Expressive Speech in the Intensive Course of a Foreign Language (Problems of the Contents of Teaching)] PhD of Pedagogical Science Thesis, Moscow, MSIof FL, pp. 1-264.

20. Manko Y.N. (1979). K voprosu ob urovnevom analize sotsialnogo vozdeystvia na formirovaniye zhiznennoy pozitsyi [To the Question of Level Analysis of Social Influence on the Formation of Socially Active Position of a Pupil. - Problems of Psychological Influence]. Ivanovo State University of the First in Russia Ivanovo-Voznesensky City-wide Soviet of Workers' Deputees, pp. 30-40. 
21. Modern Methods of Teaching Foreign Languages at School: Textbook for Teachers. ISBN 5894152909 2003. Available at: http://refleader.ru/ jgemerqasjgebew.html (accessed 23 October 2019).

22. Nwachukwu Ololube (2019). Methodological competencies of teachers: a study of Nigeria. Available at: https://www.academia.edu/.../Methodological competencies (accessed 18 October 2019).

23. Pak M.S. (2015). Problema yntehratsyy obrazovanyia y nauky.[The problem of integration of education into science](electronic journal) VYSHCHA OSVITA UKRAINY: Teoretychnyi ta naukovo-metodychnyi chasopys, no. 3. Dodatok 1: Yntehratsiia vyshchoi osvity i nauky, pp. 189-190.

24. Passov Y.I. (1980). Opredelenye ponyatia"komunikativny metod" [The Definition of the notion "communicative method"]. Problems of Communicative Teaching of Foreign Language Activity: a collection of articles, vol. 208, pp. 26-39.

25. Rekomendatsiia 2006/962/IeS Yevropeiskoho Parlamentu ta Rady (IeS) Pro osnovni kompetentsii dlia navchannia protiahom usoho zhyttia" vid 18 hrudnia 2006 roku. Available at: http://zakon2.rada.gov.ua/laws/show/994_9752; http://osvita.ua/legislation/law/2231/_2006.pdf (accessed 18 October 2019).

26. Rubinska B.I. (2013). Diialnisni kharakterystyky spilkuvannia studentiv: vyshchyi riven analizu [Activities Approach of Students' Communication:the Highest Level of Analysis]. Problemy osvity, vyp. 74, ch. I, pp. 235-236.

27. Rubinska B.I. (2018). Changes in the Category "the Choice of Content of Philologists Training" Development Trends in Pedagogical and Psychological Sciences: the Experience of Countries of Eastern Europe and Prospects of Ukraine. Riga: Latvia Baltija Publising, pp. 209-227.

28. Rubinska B.I. (2019). The choice of pedagogical situations for the formation of methodological competence of students of philology Proceedings of the Scientific Development, Advanced Technologies, Innovations: Scientific works and thesis. V International scientific and practical conference 06-08 May 2019, Prague, Nemoros s.r.o., pp. 149-156.

29. Sabljić Jakov (2014). Ways of Developing Methodological Competencies of Literature Students Academic Leadership (electronic journal). Journal of Language and Cultural Education, 2(2) ISSN 1339-4045 (print), ISSN 1339-4584. SlovakEdu 65 University of Osijek, Croatia. Available at: https://jsabljic@ffos.hr (accessed 18 October 2019).

30. Skalkin V.L. (1983). Situatsia, tema i tekst v lingvometodologytshnomu aspekti; (organyzatsya materyala dlya ustnoy retshy) [Situation, Theme and Text in Linguistic-methodological Aspect; (Organization of Material for Oral Speech)]. Russian Language Abroad, no. 3, pp. 52-58.

31. Stronin M.F. (1985). Akt retshy kak osnova obutshenya ustnoy inoyazytshnoy retshy (na material shkol s obutsheniem ryada predmetov na angliyskom yazyke. [Speech Act as the Basis of Teaching Oral Communication (based on the material of schools with teaching some subjects in English)] the $\mathrm{PhD}$ in Pedagogical Science Thesis, Moscow, APS of the USSR, pp. 1-215.

32. Carmen Avram, Pierre Larrivée (eds.) (2016). Training Foreign and second language teachers: European Challenges, Success and Perspectives, Cambridge, 
Cambridge Scholars Publishing. Available at: https://www.cambridgescholars.com/ sample (accessed 28 September 2019).

33.Tovkanets G.V., Lendel L.V., Kyrlik O.V. (2019). Formuvannya kluchovyh competentnostei yuck zavdannya kursu inozemnoi movy u pochatkoviy shkoli [The Formation of Key Competencies as the Task of Foreign Language Teaching in secondary school]. Education and Science, no. 1(26). Available at: http://dspace.msu.edu.ua:8080/jspui/handle/123456789/3330 (accessed 28 September 2019).

34.TUNING Educational Structures in Europe II Universities' contribution to the Bologna Process. University of Deusto, University of Groningen. Available at: tuningacademy.org/uploads/2014/02/TuningEUII_Final-Report_EN (accessed 19 October 2019).

35.Harkovskaya gumanitarno-pedagogicheskaya academiya: Lectsyi: Zagalni Osnovy Pedagogiky. Available at: https://studfiles.net/preview/5512173/page:105/ (accessed 19 October 2019).

36. Vaisburd M.L (1981). Typologya utshebno-retshevyh situatsyi [Typology of Teaching-Speech Situations. Psychological-pedagogical Problems of Teaching Foreign Languages: a collection of scientific papers/edited by A.D. Klimentenko, O.I. Moskalska: Moscow, Research Institute of Contents and Methods of Teaching of the Academy of Pedagogical Science of the USSR], pp. 81-91.

37. Yudin Y.E. (1981). Pro rol obutshenya retshevym situatsiam [On the Role of Teaching Speech Situations]. Psychological-pedagogical Problems of Intensive Teaching of Foreign Languages: collection of scientific papers. Moscow: The APS of the USSR, Scientific-Research Institute of Contents and Methods of Teaching, pp. 1-29.

38. Zakon Ukrainy "Pro osvitu" (Pryiniattia vid 05.09.2017. Nabrannia chynnosti 28.09.2017). Available at: http://zakon2.rada.gov.ua/laws/show/2145-19_2017.pdf (accessed 19 October 2019).

39. Zakon Ukrainy "Pro vyshchu Osvitu". Verhovna Rada of Ukraine; Zakon vid 01.07.2014 № 1556-VII. Available at: zakon.rada.gov.ua/laws/show/1556-18 (accessed 19 October 2019).

40. Zhdanko O.I. (2011). Otbor i organizatsya soderzhanya obutshenya profesionalno-napravlennoy lexike dlia studentov institute tehnologyi. [Selection and Organization of Teaching Content of the Professionally Oriented Lexis for the Students of the Institute of Technology]. Calculations Technique and Engineering Education, no. 12(4). Available at: https://www.Digital-magtti.study.ru/ lib/4/5-2011-2(4)pdf (accessed 19 October 2019).

41 Professional and methodological competencies. Available at: https://www.zhaw.ch (accessed 24.April 2019).

42. Available at: https://dictionary.cambridge.org/dictionary/english/ competency (accessed 4 April 2019). 